\title{
On High School Students' Communication Skill in Proof-Based Learning
}

\author{
D Ihdayani ${ }^{1}$, Y Hartono ${ }^{2, *}$, C Hiltrimartin ${ }^{3}, \mathrm{~J}$ Araiku$^{4}$ \\ ${ }^{1,2,3,4}$ Department of Mathematics Education, Sriwijaya University, Indonesia \\ Email: yhartono@unsri.ac.id,
}

\begin{abstract}
This research aims at describing students' mathematical communication skill through proof-based learning. This research was conducted at a senior high school in Bangka Belitung province involving 29 students. The instructional process and data collection were conducted online using Zoom Cloud Meeting application due to Covid-19 pandemic outbreak. A video about learning materials was prepared and sent to students prior to web meeting via zoom. During the meeting students were asked to work on proof-based worksheet guided by researcher. Test was then used to collect data about students' communication skill. The result shows the students' mathematical communication skills on the material of Sum and Difference of Sines and Cosines are in the sufficient category with a percentage of $52.6 \%$.
\end{abstract}

Keywords: Mathematical communication skill, proof-based learning, sum and difference of sines and cosines.

\section{INTRODUCTION}

Mathematics is important and essential in education and life mathematics is used to train a person's thinking skills in a logical and structured manner [1-3]. Mathematics is a basic science that has an important role in building technology and knowledge needed in various fields[1,4,], both in mathematics and in other fields $[3,5]$. One of the goals of learning mathematics by Permendikbud (2013) which communicate mathematical ideas with symbols, diagrams, or other media to clarify the situation or problem[6]. In NCTM (2000), communication skills are one of the components of the five learning process standards [7].

Communication skills are the ability to organize mathematical thoughts, communicate mathematical ideas, and use mathematical language to express ideas appropriately [7]. Mathematical communication ability is a tool used by students to convey arguments or ideas in learning mathematics orally or written $[1,2,8,9]$. With communication, students able to convey opinions or ideas about mathematical concepts orally or written to teachers and classmates [10], make students understand math problems, and train students to think logically, creatively, and independently [1,11]. The benefits of communication ability for students are to make them understand, interpret, express, respond, and use mathematical symbols to explain mathematical ideas orally and written [12].

In fact, students' mathematical communication skills are still low, both students with visual, auditory, and kinesthetic learning styles are still low [13, 14]. This is because students still have difficulty expressing daily events in the language of mathematics and connecting graphs with mathematical ideas [1].

The proof is an important science that must be taught in the classroom because it has the function of explaining, discovering, systematic means, creative thinking, communication tools, and verification tools [15-18]. The method of proof is needed in learning mathematics to show or prove the truth in mathematics in the form of properties or theorems [19]. Learning mathematics in the classroom using proof basedlearning can help students get to know and understand mathematics better [20]. Furthermore, the proof is a tool used to communicate mathematics [21]. Proof in mathematics is the basic understanding of mathematics to develop, build, and communicate mathematical knowledge[22, 23]. The role of proof in learning mathematics is to (1) verification the fact of a statement, (2) explain verification, (3) communicate idea mathematics, (4) make a discovery, and (5) systematics means [20]. Based on this description, the problem that will be discussed in this article is the mathematical 
communication skills of high school students in evidence-based learning.

\section{METHOD}

The method in this research is descriptive research with the aims of research to describe students' mathematical communication skills in proof-based learning. This research was held in SMA Negeri 2 Pangkalpinnag with 29 students of class XI MIA 1. The instructional process and data collection were conducted online using Zoom Cloud Meeting application due to Covid-19 pandemic outbreak. The material used in this study is the number and difference of sines and cosines. In proof-based learning, the activities that will be carried out by students are analyzing the steps of proof, proving and applying the formula. Test questions are used to measure students' mathematical communication skills. The test questions are in the form of 3 description items concerning indicators of students' mathematical communication skills.

\section{Table 1. Indicator of Students' Mathematical} Communication

\begin{tabular}{|c|c|c|}
\hline Aspect & Indicator & Descriptions \\
\hline Drawing & $\begin{array}{l}\text { Expressing } \\
\text { situations in } \\
\text { mathematical } \\
\text { ideas }\end{array}$ & $\begin{array}{l}\text { Expressing a } \\
\text { situation in model } \\
\text { mathematics } \\
\text { (sketch, tables, } \\
\text { diagrams, and } \\
\text { graphs) }\end{array}$ \\
\hline $\begin{array}{l}\text { Mathematical } \\
\text { Expression }\end{array}$ & $\begin{array}{l}\text { Expressing } \\
\text { mathematical } \\
\text { ideas }\end{array}$ & $\begin{array}{l}\text { Create models } \\
\text { of math problems } \\
\text { with symbols, } \\
\text { terms, and } \\
\text { structures } \\
\text { mathematics }\end{array}$ \\
\hline Arguments & $\begin{array}{l}\text { Explain } \\
\text { mathematical } \\
\text { ideas }\end{array}$ & $\begin{array}{l}\text { Give opinions } \\
\text { or arguments and } \\
\text { explain the } \\
\text { results of the } \\
\text { answer they get }\end{array}$ \\
\hline
\end{tabular}

The results of the student answer sheets will be analyzed using an assessment rubric and scoring guidelines. Furthermore, the researcher categorized students' mathematical communication skills according to the mathematical communication indicators.

\section{RESULT AND DISCUSSION}

\subsection{Proof-based Learning}

\subsubsection{Analysis of proving steps}

In the fourth proof of step, many students wrote down the reasons with 'displacement of the segment'. In mathematics, $2 \alpha=A+B$ should be $\alpha=\frac{1}{2}(A+B)$ obtained by multiplying the two sides by the inverse of 2 which is $\frac{1}{2}$. This is supported in Sari's (2019) research, in which students write integer operations by moving segments on algebraic material, but actually operating both segments with the same number [24].

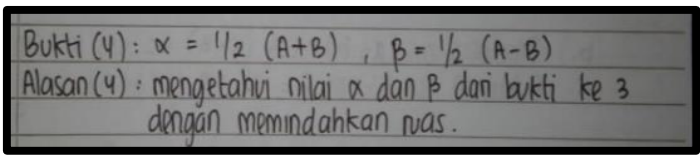

Figure 1. AM student answers

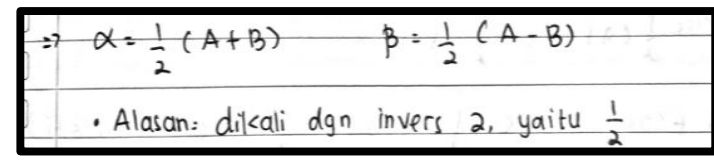

Figure 2. YC student answers

AM student answers by reason of moving segments and YC student answers with reason multiplied by inverse 2 .

\subsubsection{Proving}

Students prove proof of the formula for the number and difference of the cosine based on the steps for proving the addition of sines in question number 1.In the activity of doing proof, students write the proof according to the steps in proving question number 1 .

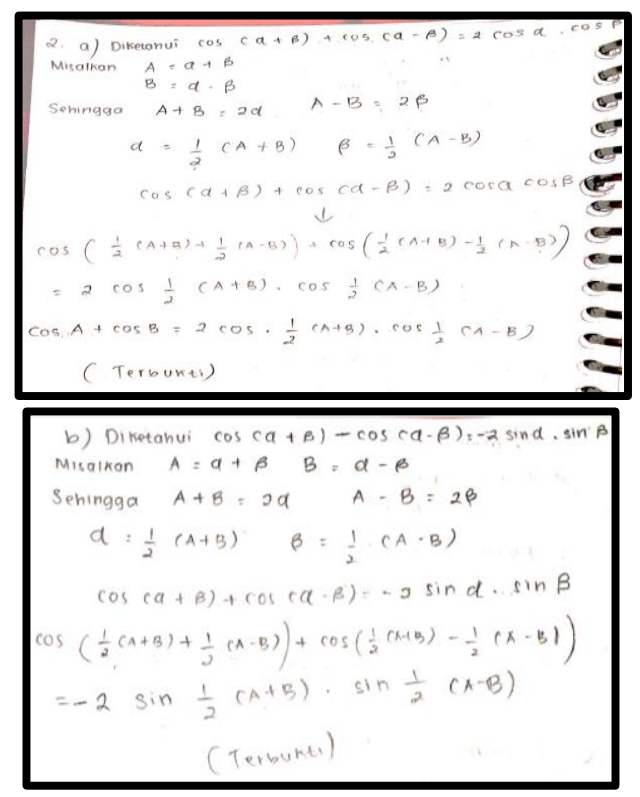

Figure 3. AC student answers 
Based on Figure 3, AC students write the proof steps for the addition and difference of the cosine clearly and the calculations are correctly.

\subsubsection{Applying the formula}

The paragraph text follows on from the subsubsection heading but should not be in italic.

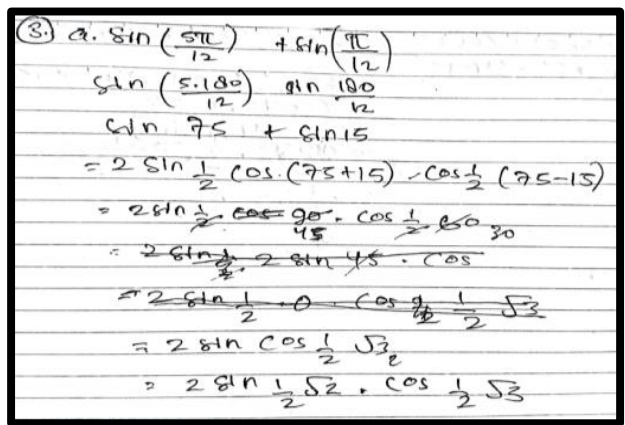

Figure 4. SK student answers

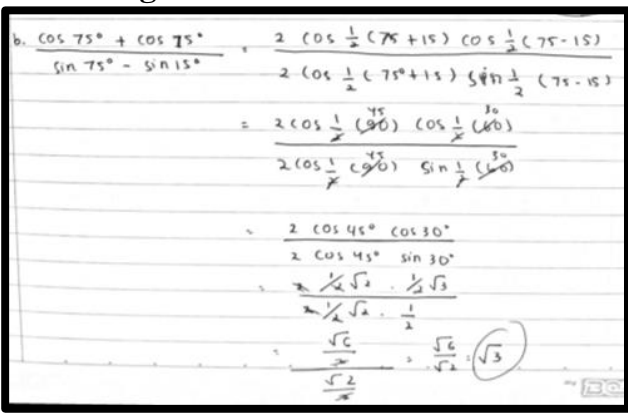

Figure 5. YC student answers

Based on figure 4, SK student wrote the formula wrong. The formula for the sum sines that should be used is $\sin A+\sin B=2 \sin \frac{1}{2}(A+B) \cdot \cos \frac{1}{2}(A-B)$, but in the student's answer write $\sin A+\sin B=$ $2 \sin \frac{1}{2} \cos (A+B) \cdot \cos \frac{1}{2}(A-B)$. So that it affects the final result of the calcution. This is supported by Shinariko's (2019) research on transformation errors, where students wrote incorrectly the ratios of the two triangles $\frac{B C}{A B}=\frac{C D}{A D}$, while the correct ratio was $\frac{A B}{C B}=\frac{D B}{D C}=$ $\frac{A D}{A B}$ [25]. Based on Figure 5, it is found that students use the sum and cosine formulas correctly and do calculations correctly.

\subsection{Mathematical Communication Skills}

\subsubsection{Expressing situations in mathematical} ideas

Andi sedang dihukum untuk berlari mengelilingi halaman sekolah. Pertama-pertama Andi berlari lurus, lalu berbelok ke kiri membentuk $\angle 90^{\circ}$. Kemudian Andi berlari beberapa meter dan berbelok ke kiri membentuk $\angle 75^{\circ}$. Lalu Andi berlari lurus hingga sampai pada tempatnya semula.

. Buatlah sketsa gambar dari situasi diatas!

Figure 6. Question number 1a

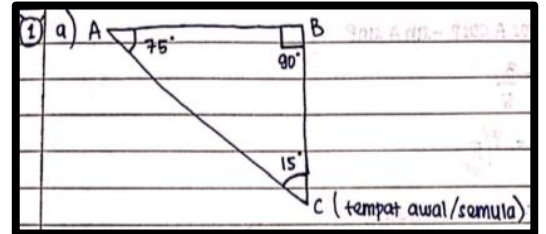

Figure 7. WP student answers

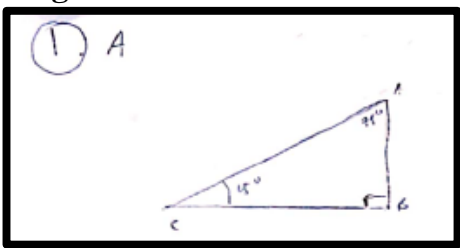

Figure 8. MI student answers

Based on Figure 7, the WP students sketched a right triangle shape, but the students did not accurately estimate the angles $\angle \mathrm{A}$ and $\angle \mathrm{C}$. In Figure 7 it can be seen that students make pictures with $\angle \mathrm{A}$ and $\angle \mathrm{C}$ look the same, $\angle \mathrm{C}$ should be made more sharp to differentiate $\angle \mathrm{A}$ and $\angle \mathrm{C}$. So that the mathematics communication of WP students in expression the situation into pictures gets a score of 4 out of 5 with an error that is describing between $\angle \mathrm{A}$ and $\angle \mathrm{C}$. This is supported by Rahmawati's research (2019), where students are lacking in expressing the SPLDV situation in the form of sketches [1]. Based on Figure 8, MI students sketched a right triangle shape, with $\angle \mathrm{A}$ and $\angle \mathrm{C}$ looking different, $\angle \mathrm{C}$ was made more sharp to distinguish $\angle \mathrm{A}$ and $\angle \mathrm{C}$. So that MI students' mathematical communication in stating the situation into pictures from known information gets a score of 5 out of 5 .

\subsubsection{Expressing Mathematical Ideas}

In questions $1 \mathrm{~b}, 2 \mathrm{a}$, and $3 \mathrm{~b}$ are used to see indicators expressing mathematical ideas on students' communication skills.

$$
\begin{aligned}
& \text { b. Tika } \angle 75^{\circ} \text { kita namakan } \angle A \text { dan } \angle 90^{\circ} \text { kita namakan } \angle B \text {, Buktikan bahwa } \cos C+ \\
& \sin C=\frac{1}{2} \sqrt{6} \text { ! }
\end{aligned}
$$

Figure 9. Question number $2 b$

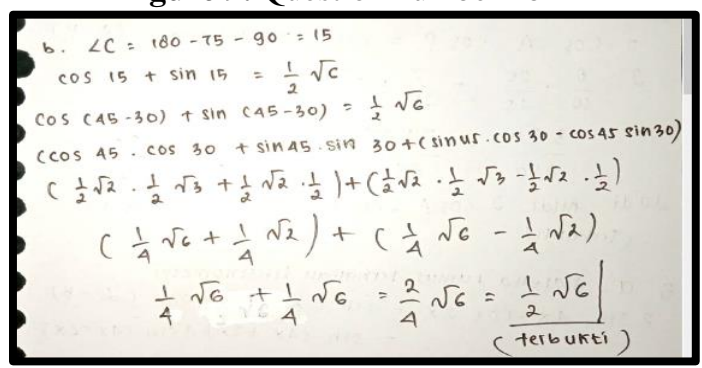

Figure 10. AM student answers 


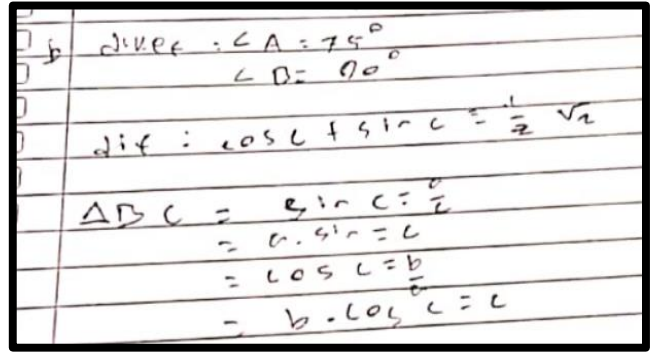

Figure 11. AA student answers

Based on Figure 10, AM students carry out the steps of the problem solving process clearly and correctly, do calculations correctly, use mathematical symbols there are still deficiencies, namely in writing angles students should write $\cos 15^{\circ}$ but students only write $\cos 15$. So that students' mathematical communication in expressing mathematical ideas gets a score of 4 out of 5 with an error, namely writing mathematical symbols. This is supported in Supriadi's (2016) research, where students are lacking in mathematical symbols, namely $\mathrm{R}$ $=\mathrm{Q}, \mathrm{P}=\mathrm{S}$, it should be $\angle \mathrm{R}=\angle \mathrm{Q}, \angle \mathrm{P}=\mathrm{S}$ [26]. Based on Figure 11, AA students answered incompletely and there were no results. From the results of interviews conducted by researchers with students, he answered that he still did not understand the material on the questions and the formula. AA students' mathematical communication in expressing mathematical ideas is still lacking and gets a score of 0 out of 5 .

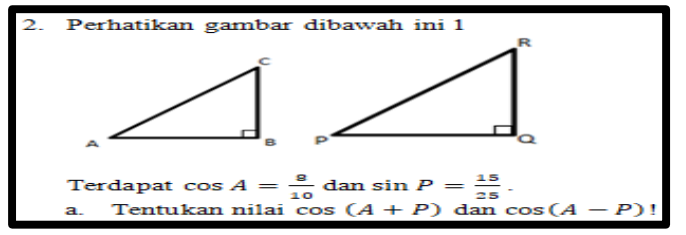

Figure 12. Question number $2 \mathrm{a}$

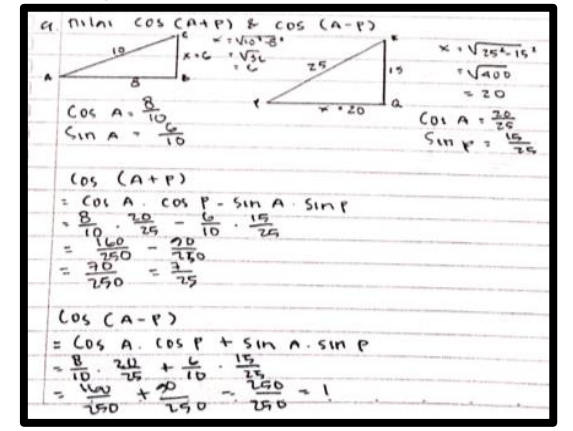

Figure 13. DC student answers

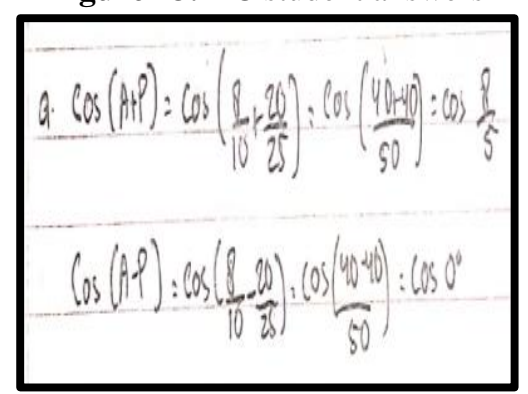

Figure 14. YF student answers
Based on Figure 13, DC students take steps to solve the solution clearly and correctly, do calculations correctly and use mathematical symbols or signs correctly [1]. So that DC students' mathematical communication in expressing mathematical ideas gets a score of 5 out of 5 . Based on Figure 14, YF students answered incorrectly by directly entering the values of $\cos \mathrm{A}$ and $\mathrm{P}$ to find $\cos (\mathrm{A}+\mathrm{P})$, not using the addition formula and the difference in cosines first. So that YF students' mathematical communication in expressing mathematical ideas gets a score of 0 out of 5. This is supported by Rahmawati's research (2019), where students are confused in applying the concept of rules that exist in SPLDV, which causes students to find it difficult to determine the results [1].

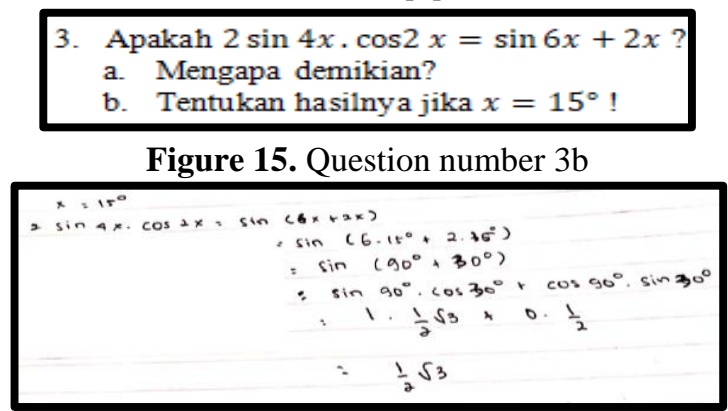

Figure 16. ER student answers

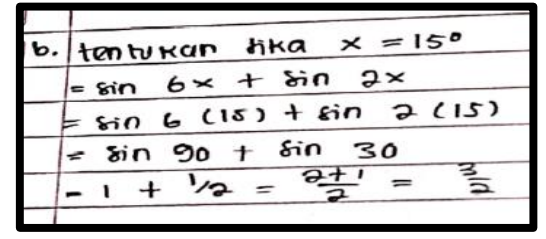

Figure 17. YF student answers

Based on Figure 16, ER students take steps to solve the solution clearly and correctly, do calculations correctly and use mathematical symbols or signs correctly [1]. So that ER students' mathematical communication in expressing mathematical ideas gets a score of 5 out of 5 . Based on Figure 17, students using mathematical symbols still have shortcomings, namely writing $\sin 90^{\circ}$, but students only write $\sin 90$, as well as other angles. So that MS students' mathematical communication in expressing mathematical ideas obtained a score of 4 with an error, namely the lack of writing mathematical symbols [1].

\subsubsection{Explain Mathematical Ideas}

In questions $2 \mathrm{~b}$ and $3 \mathrm{a}$, it is used to see indicators explain mathematical ideas on students' communication skills.

b. Dari hasil pada soal 2a, apakah $2 \cos A \cdot \cos P=\cos (A+P)+\cos (A-P)$ ? Berikan. alasannival

Figure 18. Question number 2b 


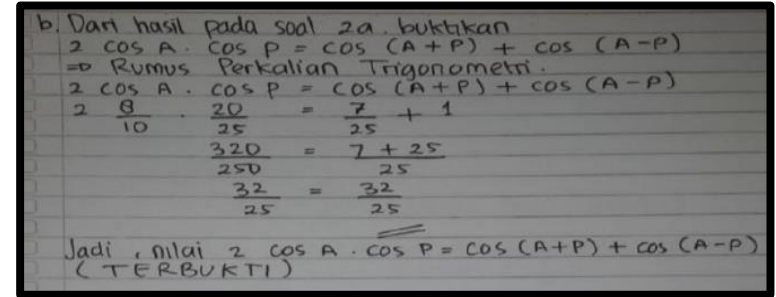

Figure 19. AM student answers

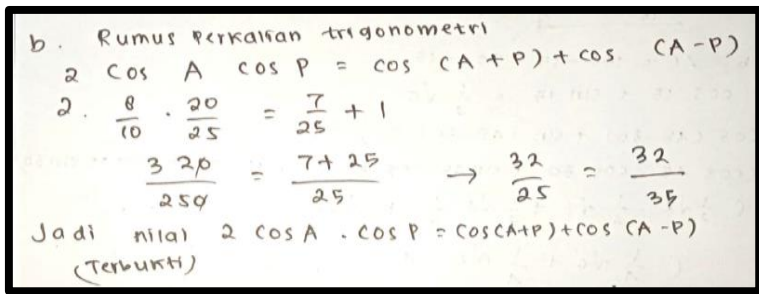

Figure 20. AC student answers

Based on pictures 19 and 20 students only write down the answers to the proof, but do not give reasons. From the results of interviews conducted by researchers, $\mathrm{AM}$ and $\mathrm{AC}$ students gave reasons, namely because the result of dari $\cos A \cdot \cos P$ was the same as the result of $\cos (A+P)+\cos (A-P)$, so that proved that $2 \cos \mathrm{A} \cdot \cos \mathrm{P}=\cos (\mathrm{A}+\mathrm{P})+\cos (\mathrm{A}-\mathrm{P})$. So that indicators explain mathematical ideas on $\mathrm{AM}$ and $\mathrm{AC}$ students' communication skills do not appear in writing, but appear orally. This is supported by Wulandari's research (2014), where students understand the steps to solve this, but do not explain the explanation or reason for the steps so that they are still lacking in indicators of providing a written explanation of the answers given [13].

$$
\begin{aligned}
& \text { 3. Apakah } 2 \sin 4 x \cdot \cos 2 x=\sin 6 x+\sin 2 x \text { ? } \\
& \text { a. Mengapa demikian? }
\end{aligned}
$$

Figure 21. Questions number 3a

a) karena menggunakan rumus perkalian fungsi trigonometri
$2 \cdot \sin 4 x \cdot \cos 2 x=\sin (4 x+2 x)+\sin (4 x-2 x)$
$2 \cdot \sin 4 x \cdot \cos 2 x=\sin 6 x+\sin 2 x$ terbukti

Figure 22. AM student answers

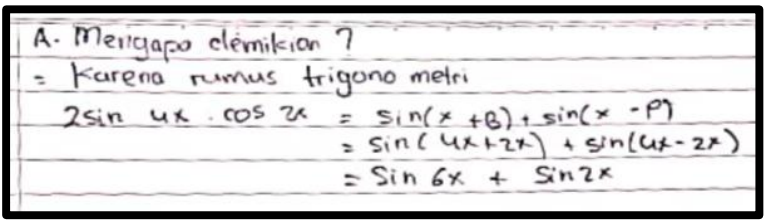

Figure 23. WH student answers

Based on figure 22, AM students wrote down the reasons asked. From the results of interviews conducted by researchers, AM students can explain the reason, namely because by calculating the value of $2 . \sin 4 x \cdot \cos 2 x$ using the trigonometric multiplication formula $2 \cdot \sin \alpha \cdot \cos \beta=\sin (\alpha+\beta)+\sin (\alpha-\beta)$ with the values $\alpha=4 x$ dan $\beta=2 x$, get the result $\sin 6 x+$ $\sin 2 x$, so it is proven that $22 \sin 4 x \cdot \cos 2 x=$ $\sin 6 x+\sin 2 x$. So that AM students' mathematical communication in explaining mathematical ideas gets a score of 5 out of 5 . Based on Figure 23, WH students are lacking in writing down reasons. So that $\mathrm{WH}$ students' mathematical communication in explaining mathematical ideas gets a score of 3 out of 5 . This is supported by Rahmawati's research (2019), namely that

Table 2. Student scores on each indicator of communication skills

Indicator
Mathematical
Communication

\section{Expressing situations} in mathematical ideas

Expressing mathematical ideas

$2,8972 \%$

Good

\section{Explain mathematical} ideas

\section{$0,91 \quad 23 \% \quad$ Very Less}

Based on the table above, of the 3 indicators of communication skills, there is only 1 indicator that is in the good category, namely expressing mathematical ideas with a percentage of $72 \%$ and a scale of 2,89 out of 4 , indicator expressing situations in mathematical ideas for the less category with a percentage of $53 \%$ and a scale of 2,14 out of 4, and indicator explain mathematical ideas for the category is very less with a percentage of $23 \%$ and a scale of 0,91 out of 4 . For the overall average, it is included in the sufficient category with a percentage of $52.6 \%$.

\section{CONCLUSION}

Based on the results and discussion previously described, it can be concluded that the mathematical communication skills of the XI MIA 1 SMA Negeri 2 Pangkalpinang students on the material of Amount and Difference of Sines and Cosines are in the sufficient category with a percentage of $52.6 \%$. With details of one indicator that is in the good category, , namely expressing mathematical ideas with a percentage of $72 \%$ and a scale of 2,89 out of 4, indicator expressing situations in mathematical ideas for the less category with a percentage of $53 \%$ and a scale of 2,14 out of 4 , and indicator explain mathematical ideas for the category is very less with a percentage of $23 \%$ and a scale of 0,91 out of 4 .

\section{ACKNOWLEDGMENTS}

We would like to give our deepest gratitude for SMA Negeri 2 Pangkal Pinang for supporting this research. The research of this article was funded by DIPA of Public Service Agency of Universitas Sriwijaya 2020. SP DIPA-023.17.2.677515/2020, 
revision 1, On March 16, 2020. In accordance with the Rector's Decree Number: 0685/UN9/SK.BUK.KP/2020, On July 15, 2020. Thanks also to Mrs. Elika Kurniadi, M.Sc., Mrs. Meryansumayeka, S.Pd., M, Sc., And Mrs. Yuyun Hikmasari, S.Pd as the instrument validator in this research.

\section{REFERENCES}

[1] N. S. Rahmawati, M. Bernand and P. Akbar, "Analisis Kemampuan Komunikasi Matematik Siswa SMK Pada Materi Sistem Persamaan Linier Dua Variabel (SPLDV)," Jurnal On Education, pp. Volume 1, No 2, 344-352, 2019.

[2] I. N. A. Khadijah, R. Maya and W. Setiawan, "ANALISIS KEMAMPUAN KOMUNIKASI MATEMATIS SISWA SMP PADA MATERI STATISTIKA," Jurnal Pembelajaran Matematika Inovatif, pp. Volume 1, No 6, 2018.

[3] A. Juliant and K. Novriarti, "Analisis Kesalahan Siswa Dalam Menyelesaikan Soal Pada Materi Pola Bilangan Ditinjau dari Kemmapuan Matematis Siswa," Jurnal Riset Pendidikan, pp. Volume 2, No 2, 2016.

[4] H. S. Tanjung, " Peningkatan Kemampuan Komunikasi dan Matematis Siswa SMA melalui Modelpembelajaran Berbasis Masalah," MAJU: Jurnal Ilmiah Pendidikan Matematika, pp. Volume 4, No 2, 2019.

[5] Purwosusilo, "Peningkatan Kemmapuan Pemahaman dan Pemecahan Masalah Matematik Siswa SMK Melalui Strategi Pembelajaran React," Jurnal Pendidikan dan Keguruan, pp. Volume 1, No 2, 2014.

[6] Permendikbud, Penilaian Hasil Belajar Oleh Pendidikan Pada Pendidikan Dasar dan Pendidikan Menengah, Jakarta: Kemendikbud, 2013.

[7] NCTM, Principles and Standards For School Mathematics, Reston, VA: National Council of Teachers of Mathematics, 2000.

[8] C. Sinaga, Kemampuan Komunikasi Matematika (Communication Matematics Ability), Research Gate: https://www.researchgate.net/publication/3218356 44, 2017.
[9] H. Hodiyanto, "Kemampuan Komunikasi Matematis Dalam Pembelajaran Matemat," Jurnal AdMathEdu, vol. 7 no 1, pp. 9-18, 2017.

[10] N. Fahradina, "Peningkatan Komunikasi Matematis dan Kemandirian Belajar Siswa SMP dengan Menggunakan Model Investigasi Kelompok," Jurnal Didaktik Matematika, pp. Volume 1, No 1, 2014.

[11] N. Islamiah, W. E. Purwaningsih, P. Akbar and M. Bernand, "Analisis Hubungan Kemampuan Pemecahan Masalah Matematis dan Self Confidence Siswa SMP," Journal On Education, pp. 47-57, 2018.

[12] J. Hernandi, "Metoda Pembuktian Dalam Matematika," Jurnal Pendidikan Matematika, pp. 1-13, 2008.

[13] S. Wulandari, A. Mirza and S. Sayu, "Wulandari, S., Mirza, A., \& Sayu, S. (2013). Kemampuan Komunikasi Matematis Siswa Ditinjau dari Gaya Belajar pada SMA Negeri 10 Pontianak," Jurnal Pendidikan dan Pembelajaran Khatulistiwa, pp. Volume 3, No 9, 2014.

[14] A. D. Wijayanto, S. N. Fajriah and I. W. Anita, "Analisis Kemampuan Komunikasi Matematis Siswa SMP Pada Materi Segitiga Dan Segiempat," Jurnal Cendekia: Jurnal Pendidikan Matematika, pp. 97-104, 2018.

[15] W. P. Thurtson, "On Proof And Progress In Mathematics Bulletin of The American Mathematical Society," pp. Volume 30, No 2, 161-177, 1994.

[16] D. Reid, "The Meaning of Proof In Mathematics Education," Proceedings of the 4th Conference of The European Society For Research In Mahematics Education, pp. 458-468, 2005.

[17] M. De Villiers, "An Illustration of The Explanatory and Discovery Functions of Proof.," Pythagoras, pp. 1-8 http://dx.doi. org/10.4102/pythagoras. v33i3.193, 2012.

[18] G. Hanna and M. De Villies, Proof and Proving in Mathematics Education: The 19 ICMI Study (Vol.15), Springer Science \& Business Media, 2008.

[19] F. S. Syafri, "Kemampuan Representasi Matematis dan Kemampuan Pembuktian Matematika," Jurnal e-DuMath, pp. Volume 3, No 1, 2017. 
[20] E. J. Knuth, "Proof as a Tool for Learning Mathematics," Mathematics Teacher-Washington Then Reston Va-, pp. 486-491, 2002.

[21] A. Schoenfeld, "What Do We Know About Mathematics Curicular," Journal of Mathematical Behavior, 1994.

[22] M. Cirillo and P. G. Herbst, "Moving toward more authentic proof practices in geometry," The Mathematics Educator, pp. Volume 21, No 2, 2012.

[23] S. Adeliza, Model Dinamis Peningkatan Pemahaman Geometri Melalui Pembuktian, TESIS. Medan: Universitas Sumatera Utara, 2017.

[24] N. Sari and S. , "Analisis Tingkat Miskonsepsi Siswa Pada Soal Aljabar," Prosiding Seminar Nasional Matematika dan Pendidikan Matematika Sesiomadika, 2019.

[25] L. J. Shinariko, N. W. Saputri, Y. Hartono and J. Araiku, "Analysis of students' mistakes in solving mathematics olympiad problems," National Conference on Mathematics Education, 2020.

[26] N. Supriadi and R. Damayanti, "Analisis Kemampuan Komunikasi Matematis Siswa Lamban Belajar Dalam Menyelesaikan Soal bangun Datar," Al-Jabar: Jurnal Pendidikan Matematika, pp. Volume 7, No 1, 1-9, 2016. 